\title{
Novel codons in rat Pdx-1 complementary DNA
}

\author{
Takayoshi Kiba*
}

\begin{abstract}
Objectives: Pancreatic and duodenal homeobox-1 (Pdx-1) is a homeodomain-containing transcription factor essential for pancreatic development, beta-cell differentiation and the maintenance of mature beta cell function. To transfect the expression vectors of Pdx-1 in the mammalian cells, the complementary DNA (cDNA) of Pdx-1 was conducted.

Results: Novel codons and amino acids sequences were detected in rat Pdx-1 CDNA. Comparing the previous reports regarding rat Pdx-1 CDNA, 3 novel codons (ACA141CCA, AAG720CCG, GTT742GCT) were detected. The amino acids sequences based on the detected cDNA sequences confirmed those, which were already available in public databases. The present study described novel codons in rat Pdx-1 cDNA. The results may be useful for an effective research against pancreatic development, regeneration or carcinogenesis regarding Pdx-1 expressions.
\end{abstract}

Keywords: $c D N A, P d x-1$, Rat

\section{Introduction}

Pancreatic and duodenal homeobox-1 (Pdx-1) is known to be a homeodomain-containing transcription factor for pancreatic development, beta-cell differentiation and the maintenance of mature beta cell function by regulating expressions of many key endocrine beta-cell-specific genes [1]. Also, Pdx-1 directly controls insulin gene expression [2] and the expression of the genes encoding glucose transporter 2 (Slc2a2) [3], islet amyloid polypeptide precursor [4], Pax 4 [5], synaptotagmin 1 [6], and Pdx-1 itself [7].

Rat chromosome 12 is associated with $\mathrm{Pdx}-1$ gene, which shares a $88 \%$ amino acid homology with human [8]. Rat Pdx-1 has two exons and it is a protein of 283 amino acids with a calculated molecular weight of $30.83 \mathrm{kDa}$. According to the functional domains and phosphorylation sites of human PDX-1, it has been reported that the sequences of 11,61, 66, 151, 231 and 232 amino acids sites, 1-79 amino acids sites, 146-206 amino acids sites, 188-203 amino acids sites, 191-196 amino acids sites and 197-203 amino acids sites are related with phosphorylation sites, transactivation sites, homeobox sites, protein

\footnotetext{
*Correspondence: takkiba@hotmail.com

Department of Life Sciences, Faculty of Science, Okayama University

of Science, 1-1 Ridai-cho, Kita-ku, Okayama-shi, Okayama 700-0005, Japan
}

transduction domain, DNA-binding motif and nuclear localization signal of Pdx-1, respectively [8].

To transfect the expression vector of Pdx-1 in the mammalian cells, when the complementary DNA (cDNA) of $\mathrm{Pdx}-1$ was conducted, the detected sequences were different from those reported before [9] (https://www.ncbi. nlm.nih.gov/nuccore/454391). In this report, the author has reported novel codons in rat Pdx-1 cDNA.

\section{Main text \\ Materials and methods \\ Animals}

A female Wistar rat weighing $140 \mathrm{~g}$ (age in 6 weeks) were used in this study. It was maintained in a temperature- and light-controlled environment $\left(23 \pm 2{ }^{\circ} \mathrm{C} ; 12\right.$-h light/12-h dark cycle) and were given free access to food and water. A rat was euthanized by cervical dislocation under anesthesia with medetomidine $(0.75 \mathrm{mg} / \mathrm{kg})$, midazolam $(4 \mathrm{mg} / \mathrm{kg})$, and butorphanol tartrate $(5 \mathrm{mg} / \mathrm{kg})$ by intraperitoneal route for the following experiments.

\section{Total RNA Preparation and CDNA synthesis}

In the present study, total RNA was isolated from fresh pancreatic tissue. The author previously described a technique that reliably improves the amount and the quality of RNA 
extracted from rat pancreas, an RNase-rich organ, using RNAlater-ICE [10]. RNA integrity was confirmed by agarose gel electrophoresis. Total RNA was reverse transcribed using PrimeScript ${ }^{\mathrm{TM}}$ Double Strand cDNA Synthesis Kit (Takara Bio Inc., Kusatsu, Japan). Synthesis of first strand cDNA was performed with oligo (dT) 18 primer and random hexamer primers simultaneously. Oligo (dT) 18 primers synthesize cDNA from the poly (A) tail mRNA, while random primers initiate cDNA synthesis from rest of the RNA population.

\section{CDNA cloning of rat Pdx-1}

Primers were designed to the $5^{\prime}$ and $3^{\prime}$ ends of rat cDNA based on the sequence from GenBank accession number NC_005111.4. The forward and reverse primers were: $5^{\prime}$ TCCGCTAGCCACCATGAATAGTGAGGAGCA $3^{\prime}$ and $5^{\prime}$ TTCGAAGCTTAAATCACCGGGGTTCCTGCGGT $3^{\prime}$, respectively. These primers were used to PCR amplify coding sequence of Pdx1 from a cDNA library originated from a rat pancreas RNA and a rat pancreas QUICKClone $^{\mathrm{TM}}$ cDNA library (Clontech Laboratories, Mountain View, CA, USA). Nhe-I and Hind-III sites were incorporated into the primers at the $5^{\prime}$ and $3^{\prime}$ ends, respectively, to allow sub-cloning into the pEGFP-N1 mammalian expression vector (Clontech Laboratories). cDNA at Pdx-1, 852 base pairs (bp), was cloned by polymerase chain reaction
(PCR) amplification, using PrimeSTAR ${ }^{\circledR}$ HS DNA Polymerase (Takara Bio Inc.) and KOD-Plus-Neo ${ }^{\circledR}$ (TOKOBO. Inc., Osaka, Japan). Polymerase Chain Reaction (PCR) was accomplished in a microtube containing $5 \mu \mathrm{L}$ of $10 \times \mathrm{PCR}$ buffer, $5 \mu \mathrm{L}$ of dNTPs (0.2 mM for each), $3 \mu \mathrm{L}$ of $\mathrm{MgCl}_{2}$ (1.5 mM), $1 \mu \mathrm{L}$ of each primer with the concentration of $10 \mu \mathrm{M}$ for each, $1-2 \mu \mathrm{L}$ of template DNA, 1 unit of PrimeS$\mathrm{TAR}^{\circledR}$ HS DNA Polymerase or KOD-Plus-Neo ${ }^{\circledR}$ and nuclease-free $\mathrm{ddH}_{2} \mathrm{O}$ up to $50 \mu \mathrm{L}$ final volume. Amplification reactions were performed in ASTEC thermocycler (Shime, Japan) and the PCR program included the following steps for all the amplicons $\left[94{ }^{\circ} \mathrm{C}: 2 \mathrm{~min}\right.$, followed by 45 cycles of denature $98{ }^{\circ} \mathrm{C}: 10 \mathrm{~s}$; extension $68^{\circ} \mathrm{C}$ : based on $30 \mathrm{~s}$ for each $\mathrm{kbp}$. PCR products were evaluated by electrophoresis using $1 \%(\mathrm{w} / \mathrm{v})$ agarose gel. Sequencing was carried out on a 3730xl DNA Analyzer (Thermo Fisher Scientific, Tokyo, Japan) at Eurofins Genomics (Tokyo, Japan).

\section{Results and discussion}

In the present study, the author used two different cDNA (a cDNA library originated from a rat pancreas RNA and a rat pancreas QUICK-Clone ${ }^{\mathrm{TM}}$ cDNA library) and two different PCR enzyme (PrimeSTAR ${ }^{\circledR}$ HS DNA Polymerase and KOD-Plus-Neo ${ }^{\circledR}$ ). These methods indicated the same results regarding Pdx-1 cDNA (Figs. 1, 2). Comparing the

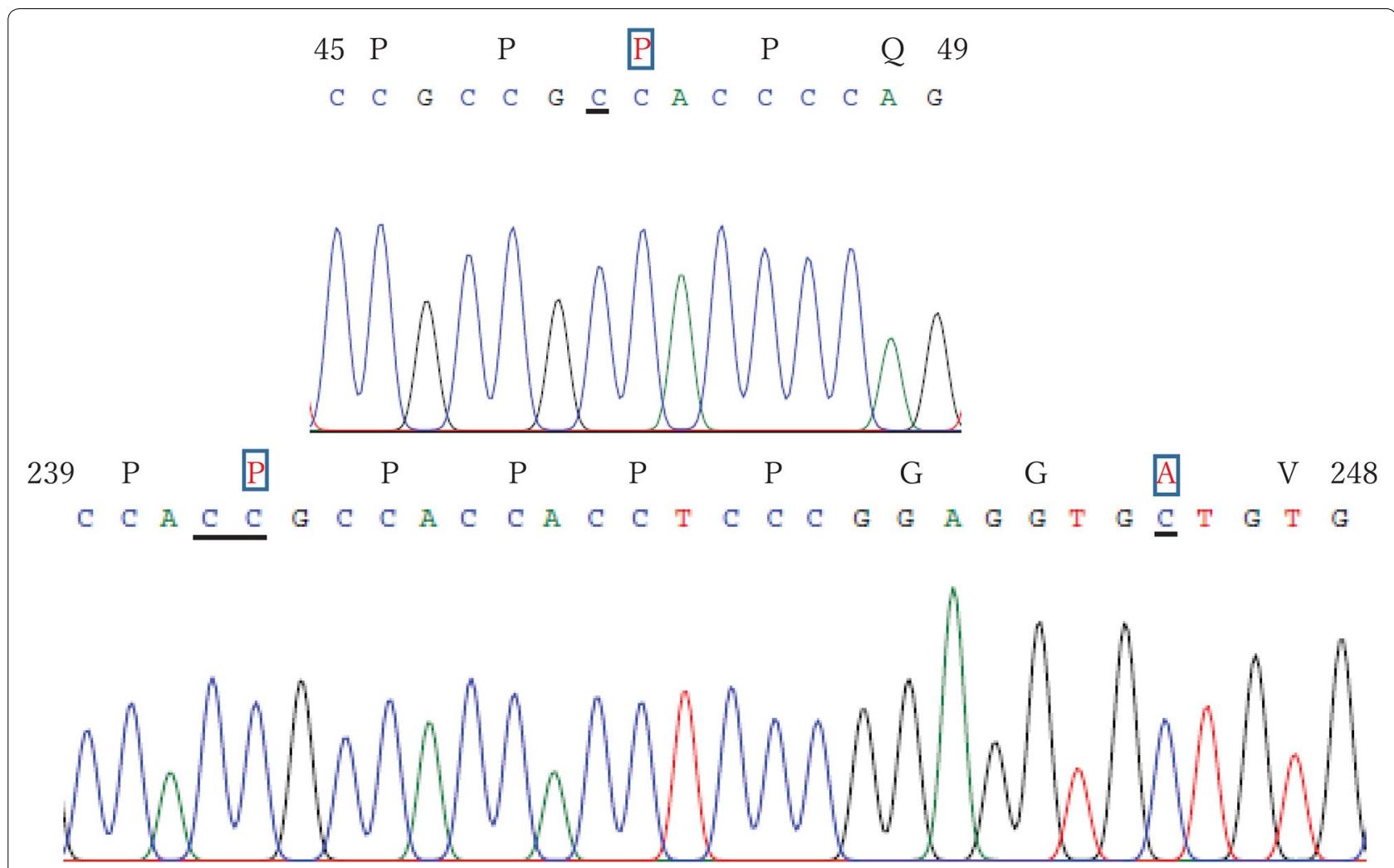

Fig. 1 The novel codons and amino acids sequence in Pdx-1 are shown. The underline regions mean the novel cDNA sequences, and the open square regions mean the amino acids sequence, which is related with the detected cDNA sequences in the present study 


\section{$\mathbf{a}_{\text {Exon } 1}$ \\ Atgaatagtgaggagcagtactacgcggccacacagctctacaaggacccgtgcgcattccagaggggtccggtgccagag ttcagtgctaatccccetgcgtgcctgtacatgggecgccagcccccacctccgcegccaccccagtttgcaggctcgctg ggaacgctggaacagggaagtcccccggacatctccccatacgaagtgcceccgctcgccgatgacccggctggcgcgcac ctccaccaccacctcccagctcagctcgggctcgcccatccacctcccggacctttcccgaatggaaccgagactgggggc ctggaagagcccagccgcgttcatctccctttcccgtggatgaaatccaccaaagctcacgcgtggaaaagccagtgggca \\ Exon 2 \\ ggaggtgcatacgcagcagaaccggaggagaataagaggacccgtacagcctacactcgggcccagctgctggagctggag aaggaattcttatttaacaatacatctcccggcctcgccgggtggagctggcagtgatgctcaacttgactgagagacac atcaaatctggttccaaaaccgtcgcatgaagtggaagaaagaggaagataagaaacgtagtagcgggacaacgagcggg ggcggtgggggcgaagagccggagcaggattgtgccgtaacctcgggcgaggagctgctggcattgccaccgccaccacct cccggaggtgctgtgccctcaggcgtccctgctgctgcccgggagggccgactgccttccggccttagtgcgtccccacag ccctccagcatcgcgecactgcgaccgcaggaaccccggtg \\ b \\ Amino acids \\ MNSEEQYYAATQLYKDPCAFQRGPVPEFSANPPACLYMGRQPPPPPPPQFAGSLGTLEQGS PPDISPYEVPPLADDPAGAHLHHHLPAQLGLAHPPPGPFPNGTETGGLEEPSRVHLPFPWM KSTKAHAWKSQWAGGAYAAEPEENKRTRTAYTRAQLLELEKEFLFNKYISRPRRVELAVMLN LTERHIKIWFQNRRMKWKKEEDKKRSSGTTSGGGGGEEPEQDCAVTSGEELLALPPPPPPG GAVPSGVPAAAREGRLPSGLSASPQPSSIAPLRPQEPR}

Fig. 2 The correct nucleic acids in Exon 1 and 2 (a) and the amino acids sequence (b) of Pdx-1, which are already available in public databases, are shown. In $\mathbf{a}$, the red collar regions mean the novel cDNA sequences and in $\mathbf{b}$, the the red collar regions mean the amino acids sequence, which is related with the detected cDNA sequences in the present study

previous reports regarding rat Pdx-1 cDNA [9] (https:// www.ncbi.nlm.nih.gov/nuccore/454391), 3 novel codons (ACA141CCA, AAG720CCG, GTT742GCT) were detected. These 3 novel codons were confirmed with genomic DNA, not cDNA, in rat chromosome 12p11, which was already reported before [11] (https://www. ncbi.nlm.nih.gov/nuccore/NC_005111.4?report=genba $\mathrm{nk} \&$ from $=9496044 \&$ to $=9501211 \&$ strand $=$ true $)$. In the present study, rat $\mathrm{Pdx}-1$ is a protein of 283 amino acids with a calculated molecular weight of $30.83 \mathrm{kDa}$, using Compute $\mathrm{pI} / \mathrm{Mw}$ tool (https://web.expasy.org/compu te_pi/). Rat Pdx-1 shares a 90\% amino acid homology with human, using Web BLAST (https://blast.ncbi.nlm. nih.gov/Blast.cgi). The amino acids sequences based on the detected cDNA sequences also confirmed those, which are already available in public databases (GenBank: EDL89565.1 and UniProtKB/Swiss-Prot: P52947.1) (Fig. 2). Therefore, the author speculates that the previous report regarding the nucleotide sequences in rat $\mathrm{Pdx}-1$ cDNA is incorrect, because the detected sequences of the cDNA of Pdx-1 were different from those reported before [9] (https://www.ncbi.nlm.nih.gov/nuccore/454391).

\section{Conclusion}

The present study described novel codons in rat $\mathrm{Pdx}-1$ cDNA. The results may be useful for an effective research against pancreatic development, regeneration or carcinogenesis regarding $\mathrm{Pd} x-1$ expressions.

\section{Limitations}

In the present study, novel codons and amino acids sequences were detected in rat Pdx-1 cDNA. Comparing the previous reports regarding rat $\mathrm{Pdx}-1 \mathrm{cDNA}$ (https:// www.ncbi.nlm.nih.gov/nuccore/454391), 3 novel codons (ACA141CCA, AAG720CCG, GTT742GCT) were detected. However, these 3 novel codons were confirmed with genomic DNA, not cDNA, in rat chromosome 12p11, which was already reported before (https://www. ncbi.nlm.nih.gov/nuccore/NC_005111.4?report=genba nk\&from $=9496044 \&$ to $=9501211 \&$ strand $=$ true). Also, the amino acids sequences based on the detected cDNA sequences confirmed those, which were already available in public databases. 


\section{Abbreviations}

CDNA: complementary DNA; PCR: polymerase chain reaction; $\mathrm{Pdx}-1$ : pancreatic and duodenal homeobox 1.

\section{Authors' contributions}

TK designed the study, collected the data, conducted data analysis, interpreted results, wrote, and revised initial and final manuscript. The author read and approved the final manuscript.

\section{Acknowledgements}

Not applicable.

\section{Competing interests}

The author declares no competing interests.

\section{Availability of data and materials}

All the information supporting our conclusions and appropriate references are included in the manuscript.

\section{Consent to publish}

Not applicable.

\section{Ethics and consent to participate}

All animal procedures were performed in according with the Guidelines for Animal Experiments at the Faculty of Science, Okayama University of Science. The Protocols were approved by the Animals Research Ethics Committee, Faculty of Science, Okayama University of Science (Approval Number 2018-16, date 5/28/18).

\section{Funding}

Not applicable.

\section{Publisher's Note}

Springer Nature remains neutral with regard to jurisdictional claims in published maps and institutional affiliations.

Received: 17 September 2018 Accepted: 9 October 2018

Published online: 12 October 2018

\section{References}

1. Jonsson J, Carlsson L, Edlund T, Edlund H. Insulin-promoterfactor 1 is required for pancreas development in mice. Nature. 1994;371(6498):606-9.

2. Zhou G, Brunicardi F. PDX1 (pancreatic and duodenal homeobox 1). Atlas Genet Cytogemet Oncol Haematol. 2011;15(6):507-10.

3. Ohlsson H, Karlsson K, Edlund T. IPF1, a homeodomain-containing transactivator of the insulin gene. EMBO J. 1993;12(11):4251-9.

4. Waeber G, Thompson N, Nicod P, Bonny C. Transcriptional activation of the GLUT2 gene by the IPF-1/STF-1/IDX-1 homeobox factor. Mol Endocrinol. 1996;10(11):1327-34.

5. Watada H, Kajimoto Y, Kaneto H, Matsuoka T, Fujitani Y, Miyazaki J, Yamasaki Y. Involvement of the homeodomain-containing transcription factor PDX-1 in islet amyloid polypeptide gene transcription. Biochem Biophys Res Commun. 1996;229(3):746-51.

6. Smith SB, Watada H, Scheel DW, Mrejen C, German MS. Autoregulation and maturity onset diabetes of the young transcription factors control the human PAX4 promoter. J Biol Chem. 2000:275(47):36910-9.

7. Nakajima-Nagata N, Sugai M, Sakurai T, Miyazaki J, Tabata Y, Shimizu A. $\mathrm{Pdx}-1$ enables insulin secretion by regulating synaptotagmin 1 gene expression. Biochem Biophys Res Commun. 2004;318(3):631-5.

8. Gerrish K, Cissell MA, Stein R. The role of hepatic nuclear factor 1 alpha and PDX-1 in transcriptional regulation of the pdx-1 gene. J Biol Chem. 2001:276(51):47775-84.

9. Miller CP, McGehee RE Jr, Habener JF. IDX-1 a new homeodomain transcription factor expressed in rat pancreatic islets and duodenum that transactivates the somatostatin gene. EMBO J. 1994;13(5):1145-56.

10. Kiba T, Kintaka Y, Nakada E, Suzuki Y, Inoue S, Ishigaki Y. High-quality RNA extraction from rat pancreas for microarray analysis. Pancreas. 2007;35(1):98-100.

11. Gibbs RA, Weinstock GM, Metzker ML, Muzny DM, Sodergren EJ, Scherer S, Scott G, Steffen D, Worley KC, Burch PE, et al. Genome sequence of the Brown Norway rat yields insights into mammalian evolution. Nature. 2004;428(6982):493-521.
Ready to submit your research? Choose BMC and benefit from:

- fast, convenient online submission

- thorough peer review by experienced researchers in your field

- rapid publication on acceptance

- support for research data, including large and complex data types

- gold Open Access which fosters wider collaboration and increased citations

- maximum visibility for your research: over $100 \mathrm{M}$ website views per year

At $\mathrm{BMC}$, research is always in progress.

Learn more biomedcentral.com/submissions 